\title{
PRAKTEK DAN PROBLEMATIK PENDIDIKAN MULTIKULTURAL DI SMK
}

\author{
Dewi Indrapangastuti \\ SMK Negeri 1 Sedayu Bantul
}

\begin{abstract}
Abstrak
Pendidikan multikultural adalah sebuah konsep yang dibuat dengan tujuan untuk menciptakan persamaan peluang pendidikan bagi semua siswa yang berbeda-beda ras, etnis, kelas sosial dan kelompok budaya, dan untuk membantu semua siswa agar memperoleh pengetahuan, sikap dan keterampilan yang diperlukan dalam menjalankan peran-peran seefektif mungkin pada masyarakat demokratik-pluralistik serta diperlukan untuk berinteraksi, negosiasi, dan komunikasi dengan warga dari kelompok beragam agar tercipta sebuah tatanan masyarakat bermoral yang berjalan untuk kebaikan bersama. Melalui pendidikan multikultural peserta didik diharapkan memiliki kompetensi yang baik, bersikap dan menerapkan nilai-nilai demokratis, humanisme dan pluralisme di sekolah dan di luar sekolah. Pendidikan multikultural diberikan kepada siswa SMK agar mereka memahami bahwa di dalam lingkungan mereka dan di lingkungan lain terdapat keragaman budaya yang berpengaruh terhadap tingkah laku, sikap, pola pikir manusia sehingga manusia tersebut memiliki cara-cara, kebiasaan, aturan-aturan bahkan adat istiadat yang berbeda satu sama lain. Bila perbedaan itu tidak dapat dipahami dengan baik dan diterima dengan bijaksana, maka konflik akan mudah terjadi baik di lingkungan sekolah maupun di lingkungan masyarakat. Penerapan konsep yang sistematis dalam mengatasi praktek dan problematik pembelajaran pendidikan multikultural yang bisa diterapkan di SMK, yaitu: a) meningkatkan peran seluruh warga sekolah, terutama guru dengan menggunakan panduan lima dimensi pendidikan multikultur dari Banks, b) mengintegrasikan materi pendidikan multikultural ke dalam kurikulum ataupun pembelajaran di sekolah dengan menggunakan panduan empat pendekatan pendidikan multikultural dari Banks, dan c) meningkatkan peran guru dalam pendidikan multikultural yaitu:1) membangun paradigma keberagamaan inklusif di lingkungan sekolah, 2) menghargai keragaman bahasa di sekolah, 3) membangun sikap sensitif gender di sekolah, 4) membangun pemahaman kritis dan empati terhadap ketidakadilan serta perbedaan sosial, 5) membangun sikap anti diskriminasi etnis, 6) menghargai perbedaan kemampuan, dan 7) menghargai perbedaan umur.
\end{abstract}

Kata kunci: praktek dan problematik, pendidikan multikultural, SMK

\section{MULTICULTURAL EDUCATION PRACTICE AND PROBLEMATIC IN VOCATIONAL HIGH SCHOOI}

\begin{abstract}
Multicultural education is a concept that was made by the purpose to create equality of educational opportunities for all students of different racial, ethnic, social classes and cultural groups, and to help all students to acquire knowledge, attitudes and skills needed in their roles as effectively as possible in a pluralistic and democratic society, to interact, negotiate, and communicate with citizens of diverse groups in order to a moral society which run for the common value. Multicultural education is expected to be easily understood, mastered, and applied democraticly by students. The importance of multicultural education is given to vocational students in the hope that they understand that in their environments and other environments are also in cultural diversity. The cultural diversity affects behavior, attitudes, patterns of human thought that humans could have ways (usage), habit (folk Airways), rules (mores) even mores (customs) are different from each other. If the difference is not well understood and accepted by the wise, the conflict (such as the fight between the studens) will easily occur both within the school and community environments. It is required a systematic effort of applying the concept and practice in dealing with problematic learning that can be applied to multicultural education in vocational schools, namely: a) increasing the role of all citizens of the school, especially teachers using the guidelines of the five dimensions of Banks' multicultural education, b) integrating multicultural education materials into curriculum or teaching in schools by using the four guidelines multicultural education approach of Banks, and c) enhancing the role of teachers in multicultural education, namely: 1) building inclusive paradigm of diversity in the school environment, 2) appreciate the diversity of language in schools, 3) building a sensitive manner gender in school, 4) building a critical understanding and empathy for the injustices and social difference, 5) building anti ethnic discrimination, 6) appreciating differences, and 7) appreciating differences of age.
\end{abstract}

Keywords: practice and problematic, multicultural education, SMK 


\section{PENDAHULUAN}

Undang-undang Dasar 1945 (Pasal 31 ayat 3), dengan tegas menunjukkan bahwa arah dan tujuan pendidikan nasional adalah peningkatan iman dan takwa serta pembinaan akhlak mulia para peserta didik. Keluarnya Undang-undang Sis-tem Pendidikan Nasional (Sisdiknas), yakni UU No. 20 Tahun 2003, menegaskan kembali fungsi dan tujuan pendidikan nasional tersebut. Pada Pasal 3 UU ini ditegaskan, Pendidikan nasional berfungsi mengembangkan kemampuan dan membentuk watak serta peradaban bangsa yang bermartabat dalam rangka mencerdaskan kehidupan bangsa, bertujuan untuk berkembangnya potensi peserta didik agar menjadi manusia yang beriman dan bertakwa kepada Tuhan Yang Maha Esa, berakhlak mulia, sehat, berilmu, cakap, kreatif, mandiri, dan menjadi warga negara yang demokratis serta bertanggung jawab. Sisdiknas merupakan acuan untuk mendidik dan membangun manusia seutuhnya.

Dalam Sisdiknas pasal 4, tercantum pula prinsip-prinsip penyelenggaraan pendidikan, yaitu: (1) Pendidikan diselenggarakan secara demokratis dan berkeadilan serta tidak diskriminatif dengan menjunjung tinggi hak asasi manusia, nilai keagamaan, nilai kultural, dan kemajemukan bangsa, (2) Pendidikan diselenggarakan sebagai satu kesatuan yang sistemik dengan sistem terbuka dan multimakna, (3) Pendidikan diselenggarakan sebagai suatu proses pembudayaan dan pemberdayaan peserta didik yang berlangsung sepanjang hayat, (4) Pendidikan diselenggarakan dengan memberi keteladanan, membangun kemauan, dan mengembangkan kreativitas peserta didik dalam proses pembelajaran, (5) Pendidikan diselenggarakan dengan mengembangkan budaya membaca, menulis, dan berhitung bagi segenap warga masyarakat, dan (6) Pendidikan diselenggarakan dengan memberdayakan semua komponen masyarakat melalui peran serta dalam penyelenggaraan dan pengendalian mutu layanan pendidikan.

Dari paparan di atas, sebenarnya pemerintah Indonesia sudah memberikan ruang yang cukup untuk terselenggaranya pendidikan nasional yang sesuai dengan kebhinekaan bangsa Indonesia. Seperti kita ketahui bahwa Indonesia adalah salah satu negara yang multikultural terbesar di dunia, kebenaran dari pernyataan ini dapat dilihat dari sosio kultur maupun geografis yang begitu beragam dan luas. Di wilayah NKRI terdapat sekitar kurang lebih 13.000 pulau besar dan kecil, dan jumlah penduduk kurang lebih 240 juta jiwa,terdiri dari 300 suku bangsa yang menggunakan hampir 200 bahasa yang berbeda. Selain itu juga menganut agama dan kepercayaan yang beragam seperti Islam, Katholik, Kristen Protestan, Hindu, Budha, dan Konghucu, serta berbagai macam kepercayaan.

Akan tetapi banyak orang yang belum juga menyadari bahwa kemajemukan tersebut juga menyimpan potensi konflik yang dapat mengancam kehidupan berbangsa dan bernegara. Keragaman ini diakui atau tidak, akan dapat menimbulkan berbagai persoalan seperti yang sekarang dihadapi bangsa ini. Korupsi, kolusi, nepotisme, premanisme, perseteruan politik, kemiskinan, kekerasan, separatisme, perusakan lingkungan, dan hilangnya rasa kemanusiaan.

Salah satu institusi pendidikan di Indonesia yang banyak diberitakan di media massa dengan berbagai perilaku negatifnya adalah Sekolah Menengah Kejuruan (SMK), di antaranya adalah perkelahian antar geng (seperti geng motor), tawuran massal antar sekolah yang kerap terjadi, bahkan dengan berbagai senjata tajam yang banyak disita polisi, dan sebagainya.

Untuk mengatasi problema tersebut harus dilakukan melalui pendidikan, dengan cara membangun kultur pendidikan nilai di sekolah. Oleh sebab itu adalah sangat penting untuk menanamkan pendidikan nilai di SMK, untuk mencegah terjadinya perilaku yang tidak diinginkan. Berkaitan dengan hal tersebut, untuk membangun rasa kebersamaan, sekaligus menjawab berbagai problematika kemajemukan seperti yang digambarkan di atas dibutuhkan suatu langkah yang sistematis. Dalam tulisan ini penulis menawarkan satu alternatif sebagai suatu upaya untuk mengatasi problema melalui penerapan konsep pendidikan multikultural yang berbasis pada pemanfaatan keragaman yang ada di masyarakat, khususnya yang ada pada siswa seperti keragaman etnis, budaya, bahasa, agama, status sosial, gender, kemampuan, umur dan ras. Konsep pendidikan multikultural ini bertujuan agar siswa SMK memiliki kesadaran berperilaku humanis, pluralis, dan demokratis.

Pentingnya pendidikan multikultural diberikan kepada siswa SMK dengan harapan 
agar mereka mampu memahami bahwa di dalam lingkungan mereka dan juga di lingkungan lain terdapat keragaman budaya. Keragaman budaya tersebut berpengaruh terhadap tingkah laku, sikap, pola pikir manusia sehingga manusia tersebut memiliki cara-cara (usage), kebiasaan (folk ways), aturan-aturan (mores) bahkan adat istiadat (customs) yang berbeda satu sama lain. Bila perbedaan itu tidak dapat dipahami dengan baik dan diterima dengan bijaksana, maka konflik (seperti perkelahian antar pelajar) akan mudah terjadi baik di lingkungan sekolah maupun di lingkungan masyarakat.

Lingkungan pendidikan SMK adalah sebuah sistem yang terdiri dari banyak faktor, seperti: kultur sekolah, kebijakan sekolah, serta formalisasi kurikulum dan bidang studi. Bila dalam hal tersebut terjadi perubahan maka hendaklah perubahan itu fokusnya untuk menciptakan dan memelihara lingkungan SMK dalam kondisi multikultural yang efektif. Tujuan utama dari pendidikan multikultural adalah mengubah pendekatan pelajaran dan pembelajaran ke arah memberi peluang yang sama pada setiap siswa. Jadi tidak ada yang dikorbankan demi persatuan. Siswa ditanamkan pemikiran lateral, keanekaragaman, dan keunikan itu dihargai. Ini berarti harus ada perubahan sikap, perilaku, dan nilainilai khususnya civitas akademika SMK.

\section{PEMBAHASAN}

\section{Pengertian Pendidikan Multikultural}

Sebagai sebuah wacana baru, pengertian pendidikan multikultural sesungguhnya hingga saat ini belum begitu jelas dan masih banyak pakar pendidikan yang memperdebatkannya. Namun demikian, bukan berarti bahwa definisi pendidikan multikultural tidak ada atau tidak jelas. Sebetulnya sama dengan definisi pendidikan yang penuh penafsiran antara satu pakar dengan pakar lainnya di dalam menguraikan makna pendidikan itu sendiri. Hal ini juga terjadi pada penafsiran tentang arti pendidikan multikultural.

Menurut Brant dalam Billilng \& Gillborn (2004, p.37) multikulturisme difokuskan untuk menyediakan informasi dan meningkatkan kesadaran tentang etnisisme, budaya, kesetaraan, kesalahpahaman prejudice, dan kebodohan.
Modood dalam Zamroni (2008, p.75) menyatakan bahwa ide kewarganegaraan yang multikultural adalah kritik dari asimilasi budaya tradisional yang dituntut oleh kaum migran dan minoritas, serta individualisme liberal yang tidak memiliki ruang untuk kelompok. Namun, didasarkan pada pengembangan dari ide-ide kesetaraan individu dan kewarganegaraan yang demokratis.

Pendidikan multikultural sebagai sebuah kebijakan sosial yang didasarkan pada prinsip-prinsip pemeliharaan budaya dan saling memiliki rasa hormat antara seluruh kelompok budaya di dalam masyarakat. Pendidikan multikultural pada dasarnya merupakan program pendidikan bangsa agar komunitas multikultural dapat berpartisipasi dalam mewujudkan kehidupan demokrasi yang ideal bagi bangsanya (Banks, 2007). Lebih lanjut Banks mengatakan bahwa pendidikan multikultur dapat didefinisikan menurut tiga hal, yaitu ide atau konsep (idea or concept), gerakan reformasi (reform movement), dan proses berkelanjutan (ongoing process). Sebagai ide, pendidikan multikultural mengandung makna bahwa semua peserta didik, tanpa memperhatikan gender, status sosial, suku, ras atau karakteristik budaya, wajib memperoleh kesempatan yang sama untuk belajar di sekolah. Sebagai gerakan reformasi, pendidikan multikultur dirancang untuk membuat perubahan di sekolah dan isntitusi pendidikan sehingga seluruh peserta didik dari semua kelas sosial, gender, ras, dan kelompok budaya dapat memperoleh kesempatan yang sama untuk belajar. Sebagai proses berkelanjutan, pendidikan multikultural adalah proses terus menerus diterapkan di segala aspek pendidikan di sekolah dengan tujuan persamaan hak memperoleh pendidikan dan meningkatkan prestasi akademik untuk mencapai potensi tertinggi dirinya sebagai manusia (the highest potentials as human beings) yang mungkin tidak pernah tercapai sempurna tapi tetap terus diupayakan (Banks, 2007, p.82).

Sleeter \& Grant dan Smith mendefinisikan pendidikan multikultural sebagai suatu pendekatan progresif untuk melakukan transformasi pendidikan yang secara holistik memberikan kritik dan menunjukkan kelemahankelemahan, kegagalan-kegagalan dan diskriminasi yang terjadi di dunia pendidikan (saat ini). Sedangkan Nieto memahami pendidikan multikultural sebagai suatu bentuk pendidikan 
yang bertumpu pada keadilan sosial, kesetaraan pendidikan dan suatu dedikasi guna memberikan pengalaman pembelajaran di mana seluruh siswa dapat mencapai perkembangan secara optimal (Zamroni, 2011, p.144).

Menurut Zamroni (2011, p.33) pendidikan multikultural di Amerika Serikat adalah suatu kebijakan yang lahir dari kesadaran mendalam bahwa masyarakat harus menghargai dan menjunjung tinggi adanya perbedaan, antara lain realitas keberadaan berbagai etnis, suku bangsa, bahasa, dan kultur masyarakat, sehingga memerlukan keberadaan sistem dan praktek pendidikan yang bersifat adil setara sehingga semua siswa tanpa melihat latar belakangnya bisa mendapatkan pelayanan pendidikan yang layak untuk mencapai prestasi optimal. Lebih lanjut Zamroni menyatakan bahwa pendidikan multikultural bukan sekedar perubahan di bidang kurikulum atau perubahan dalam proses pembelajaran, melainkan dikonseptualisasikan sebagai gerakan reformasi pendidikan untuk menghilangkan penindasan dan ketidakadilan sehingga terwujud keadilan dan kesetaraan dalam pendidikan, yang menjamin semua siswa akan berhasil mencapai prestasi maksimal, sesuai dengan minat, bakat, dan ketertarikannya (Zamroni, 2011, p.145).

Nieto dalam Noel $(2000$, p.300) mengemukakan karakteristik dasar pendidikan multikultural adalah sebagai berikut: 1) pendidikan multikultural adalah pendidikan antiracist (anti rasis), 2) pendidikan multikultural adalah pendidikan dasar, 3) pendidikan multikultural adalah penting untuk seluruh siswa, 4) pendidikan multikultural adalah pervasive (spektrumnya luas), 5) pendidikan multikultural adalah untuk social justice (keadilan sosial), 6) pendidikan multikultural adalah suatu proses, dan 7) pendidikan multikultural adalah critical pedagogy (pedagogi kritis).

Tujuan pendidikan multikultur menurut Banks (2002, pp.1-2) adalah: 1) untuk membantu individu mendapatkan pemahaman diri yang lebih besar dengan melihat diri dari sudut pandang budaya lain; 2) untuk memberikan siswa suatu alternatif budaya dan etnis; 3) untuk menyediakan keterampilan, sikap, dan pengetahuan yang dibutuhkan semua siswa untuk berfungsi dalam budaya etnis mereka, dalam budaya mainstream, dan dalam dan lintas budaya etnis lainnya; serta 4) untuk mengurangi rasa sakit dan diskriminasi bahwa pengalaman anggota dari beberapa kelompok etnis dan ras karena karakteristik unik mereka ras, fisik, dan budaya.

Zamroni (2011, p.152) mengemukakan beberapa tujuan yang akan dikembangkan pada diri siswa dalam proses pendidikan multikultural, yaitu:

a. Siswa memiliki critical thinking yang kuat, sehingga bisa mengkaji materi yang disampaikan secara kritis dan konstruktif.

b. Siswa memiliki kesadaran atas sifat curiga atas pihak lain yang dimiliki, dan mengkaji mengapa dan dari mana sifat itu muncul, serta terus mengkaji bagaimana cara menghilangkan sifat curiga tersebut.

c. Siswa memahami bahwa setiap ilmu bagaikan sebuah pisau bermata dua, ada sisi baik dan ada sisi buruk. Semua tergantung pada yang memiliki ilmu tersebut.

d. Siswa memiliki keterampilan untuk memanfaatkan dan mengimplementasikan ilmu yang dikuasai.

e. Siswa bersifat sebagai a learning person, belajar sepanjang hayat masih di kandung badan.

f. Siswa memiliki cita-cita untuk menempati posisi sebagaimana ilmu yang dipelajari. Namun, juga menyadari bahwa posisi tersebut harus dicapai dengan kerja keras.

g. Siswa dapat memahami keterkaitan apa yang dipelajari dengan kondisi dan persoalan yang dihadapi bangsa.

Berdasarkan pendapat dari para ahli di atas, dapat dikatakan bahwa pendidikan multikultural adalah sebuah konsep yang dibuat dengan tujuan untuk menciptakan persamaan peluang pendidikan bagi semua siswa yang berbeda-beda ras, etnis, kelas sosial dan kelompok budaya. Tujuan penting lainnya dari konsep pendidikan multikultural adalah untuk membantu semua siswa agar memperoleh pengetahuan, sikap dan keterampilan yang diperlukan dalam menjalankan peranperan seefektif mungkin pada masyarakat demokratik-pluralistik serta diperlukan untuk berinteraksi, negosiasi, dan komunikasi dengan warga dari kelompok beragam agar tercipta sebuah tatanan masyarakat bermoral yang berjalan untuk kebaikan bersama. Melalui pendidikan multikultural peserta didik diharapkan dapat dengan mudah memahami, menguasai, memiliki kompetensi yang baik, 
bersikap dan menerapkan nilai-nilai demokratis, humanisme dan pluralisme di sekolah dan di luar sekolah. Pendidikan di alam demokrasi seperti Indonesia harus berorientasi pada kepentingan bangsa yang berlatar belakang multi-etnic, multi-religion, multi-language dan lain-lain. Hal ini berarti bahwa penyelenggara pendidikan harus memperhatikan ragam kondisi bangsa yang heterogen.

\section{Paradigma Pendidikan Multikultural}

Banks (1993, p.3) menyatakan bahwa pendidikan multikultural secara umum sebagai pendidikan untuk people of color, artinya pendidikan multikultural ingin mengeksplorasi perbedaan sebagai keniscayaan. Pendidikan multikultural adalah ide atau falsafah sebagi suatu rangkaian kepercayaan dan penjelasan yang mengakui dan menilai pentingnya keragaman budaya, identitas pribadi, kesempatan pendidikan dari individu, kelompok maupun negara. Lebih lanjut Banks (2001, p.28) menyatakan bahwa pendidikan multikultural adalah konsep atau ide sebagai suatu rangkaian kepercayaan (set of believe) dan penjelasan yang mengakui dan menilai pentingnya keragaman budaya dan etnis dalam membentuk gaya hidup, pengalaman sosial, identitas pribadi dan kesempatankesempatan pendidikan dari individu, kelompok maupun negara.

Pendidikan multikultural adalah suatu kebijakan yang lahir dari kesadaran yang mendalam bahwa masyarakat harus menghargai dan menjunjung tinggi adanya berbagai perbedaan, antara lain realitas keberadaan berbagai macam etnis, suku bangsa, bahasa, dan kultur masyarakat, sehingga memerlukan keberadaan sistem dan praktek pendidikan yang bersifat adil setara sehingga semua siswa tanpa melihat latar belakangnya bisa mendapatkan pelayanan pendidikan yang layak untuk mencapai prestasi optimal. Keberadaan sistem dan praktek pendidikan semacam ini merupakan prasyarat mewujudkan masyarakat yang demokratis. Mewujudkan pendidikan yang demokratis memerlukan beberapa persyaratan pokok antara lain: a) praktik pendidikan di sekolah-sekolah dilaksanakan berdasarkan pada prinsip keadilan dan kesetaraan; b) proses pembelajaran dijauhkan dari sifat bias dan stereotip; dan c) Proses pembelajaran harus berujung pada pengembangan kemampuan kultural pada diri siswa (Zamroni, 2011, pp.33-34).

Zamroni (2011, pp.147-148) menyatakan bahwa pendidikan multikultural adalah suatu gerakan pembaharuan dan proses untuk menciptakan lingkungan pendidikan yang setara untuk seluruh siswa, yang memiliki prinsip sebagai berikut: a) pendidikan multikultural adalah gerakan politik yang bertujuan menjamin keadilan sosial bagi seluruh warga masyarakat tanpa memandang latar belakang yang ada; b) pendidikan multikultural mengandung dua dimensi: level kelas, yakni pembelajaran, dan level sekolah, yakni kelembagaan, antara keduanya tidak bisa dipisahkan, tetapi justru harus ditangani lewat reformasi yang komprehensif; c) pendidikan multikultural menekankan pada perlunya analisis kritis atas sitem kekuasaan dan privilages untuk dapat dilakukannya reformasi komprehensif dalam pendidikan; d) tujuan pendidikan multikultural adalah menyediakan bagi setiap siswa jaminan memperoleh kesempatan guna mencapai prestasi maksimal sesuai dengan kemampuan, minat, dan bakat yang dimiliki; e) pendidikan multikultural merupakan pendidikan yang baik untuk seluruh siswa, tanpa memandang latar belakangnya.

Lebih lanjut Zamroni (2011, p.146) menawarkan paradigma pendidikan multikultural sebagai berikut: a) pendidikan multikultural bisa menjadi jantung bagi proses untuk menciptakan kesetaraan pendidikan bagi seluruh warga masyarakat; b) pendidikan multikultural bukan sekedar dari perubahan kurikulum atau perubahan metode pembelajaran; c) pendidikan multikultural sebagai proses transformasi kesadaran yang memberikan arah ke mana transformasi praktek pendidikan harus menuju; dan d) pendidikan multikultural bertujuan untuk membangun jembatan antara kurikulum dan karakter guru, pedagogik, iklim kelas, dan kultur sekolah guna membangun visi sekolah yang menjunjung kesetaraan.

Pendidikan multikultural merupakan proses pengembangan sikap dan tata laku seseorang atau sekelompok orang dalam usaha mendewasakan manusia melalui upaya pengajaran, pelatihan, proses, perbuatan, dan caracara mendidik yang menghargai pluralitas dan heterogenitas secara humanistik. Pendidikan multikultural mengandung arti bahwa proses pendidikan yang diimplementasikan pada kegiatan pembelajaran di satuan pendidikan 
selalu mengutamakan unsur perbedaan sebagai hal yang biasa, sebagai implikasinya pendidikan multikultural membawa peserta didik untuk terbiasa dan tidak mempermasalahkan adanya perbedaan secara prinsip untuk bergaul dan berteman dengan siapa saja tanpa membedakan latar belakang budaya, suku bangsa, agama, ras, maupun adat istiadat yang ada.

\section{Pentingnya Pendidikan Multikultural di Indonesia}

Indonesia merupakan sebuah bangsa yang mempunyai banyak sekali keragaman, baik dari segi suku bangsa, agama, ras, maupun golongan. Keragaman yang ada tersebut sangat memungkinkan terjadinya sikap-sikap primordialisme maupun etnosentrisme yang dapat memicu konflik. Apabila keragaman tersebut mampu dilihat sebagai kekayaan sosiobudaya, maka akan menuju pada integrasi bangsa. Namun sebaliknya, apabila keragaman yang dipicu oleh sikap primordial dan etnosentris tersebut tidak bisa ditanggulangi dengan baik, maka bukan tidak mungkin akan memunculkan disintegrasi bangsa.

Di lain pihak, kita menyadari bahwa interaksi dengan budaya global merupakan keniscayaan yang tidak perlu ditakutkan, justru semestinya dapat dimanfaatkan untuk memperkaya nilai-nilai sosial budaya dengan nilai-nilai luhur yang bersifat universal. Hal ini menunjukan sifat keterbukaan yang dimiliki oleh sistem sosial budaya kita belum sepenuhnya dapat dimanfaatkan secara tepat dan produktif.

Oleh karena itu, untuk memunculkan sikap toleransi, serta saling memahami dalam konteks lintas budaya, maka perlu diberlakukan suatu sistem pendidikan yang multikultur. Pendidikan multikultur ini mempunyai peran yang sangat strategis dalam membekali seseorang menghadapi era globalisasi sehingga tidak hanyut dalam dampak negatif globalisasi. Selain itu pula pendidikan multikultural ini berperan untuk menyatukan budaya bangsa, dalam arti tidak menjadikan budaya yang ada menjadi seragam, namun keberagaman yang dipandang sebagai kekayaan bangsa yang patut dijaga bersama. Jika peran dan tujuan tersebut tercapai secara maksimal, maka integrasi, persatuan dan kesatuan bangsa Indonesia akan tercapai.
Pemahaman dan akselarasi pendidikan yang berbasis multikultural menjadi sangat penting untuk dihayati bagi generasi muda. Terutama untuk diaplikasikan dalam kehidupan sehari-hari. Pemahaman dari awal mengenai multikultural setidaknya akan mempengaruhi perkembangan generasi muda Indonesia di masa yang akan datang. Oleh karena itu proses pendidikan yang berbasis multikultural, tidak saja berlangsung di sekolah namun juga luar sekolah yakni di masyarakat dan keluarga. Dengan demikian diharapkan akan terjadi kerukunan antara suku/etnik yang berbeda-beda dan secara bersama-sama membangun bangsa dan negara yang tercinta Indonesia.

\section{Karakteristik Pendidikan Nilai di SMK}

Pendidikan nilai-nilai di Sekolah Menengah Kejuruan (SMK) harus memberikan akses dan kesempatan kepada peserta didik untuk mempraktekkan dan menerapkan jenis pengetahuan, kompetensi, dan sikap dalam proses mempersiapkan mereka untuk hidup di masyarakat yang kompleks saat ini. SMK harus memiliki kepedulian dan mempromosikan nilai-nilai pendidikan, keunggulan dan standar yang tinggi sebagai aspirasi individu dan kelembagaan, berprestasi dan melakukan dalam semua aspek kegiatannya. SMK harus humanis dan memberi kesempatan yang luas kepada peserta didik untuk mendapatkan nilai-nilai yang akan sangat penting dalam pengembangan pribadi dan sosial. Sekolah harus mengembangkan rasa kemerdekaan dan harga diri peserta didik sebagai manusia, memiliki kepercayaan diri untuk berkontribusi pada masyarakat, menjadi bagian dari masyarakat dalam tatanan kehidupan sosial politik yang berbudaya dan bermoral.

SMK harus mempersiapkan masa depan peserta didik sebagai anggota masyarakat dan warga negara untuk melakukan hubungan interpersonal satu sama lain, dengan cara yang tidak bertentangan dengan norma dalam masyarakat SMK harus menyiapkan peserta didik untuk memiliki kepedulian kepada pendidikan multikultural di samping pendidikan keterampilan. SMK harus menggabungkan pendidikan untuk otonomi pribadi yang rasional, pengembangan pendidikan multikultural dan berkontribusi sosial untuk kebahagiaan, kesejahteraan, dan kedamaian. 


\section{Pentingnya Pendidikan Multikultural di SMK}

Menurut Jose A. Cardinas (1975, p.131), pentingnya pendidikan multikultural didasarkan pada lima pertimbangan: (1) incompatibility (ketidakmampuan hidup secara harmoni), (2) other languages acquisition (tuntutan bahasa lain), (3) cultural pluralism (keragaman kebudayaan), (4) development of positive selfimage (pengembangan citra diri yang positif), dan (5) equility of educational opportunity (kesetaraan memperoleh kesempatan pendidikan). Di pihak lain, Donna M. Gollnick (1983, p.29) menyebutkan bahwa pentingnya pendidikan multikultural dilatarbelakangi oleh beberapa asumsi: (1) bahwa setiap budaya dapat berinteraksi dengan budaya lain yang berbeda, dan bahkan dapat saling memberikan kontribusi; (2) keragaman budaya dan interaksinya; (3) keadilan sosial dan kesempatan yang setara bagi semua orang merupakan hak bagi semua warga negara; (4) distribusi kekuasaan dapat dibagi secara sama kepada semua kelompok etnik; (5) sistem pendidikan memberikan fungsi kritis terhadap kebutuhan kerangka sikap dan nilai demi kelangsungan masyarakat demokratis; serta (6) para guru dan para praktisi pendidikan dapat mengasumsikan sebuah peran kepemimpinan dalam mewujudkan lingkungan yang mendukung pendidikan multikultural.

SMK harus mencari dan menemukan sebuah pendekatan untuk membangun dan menawarkan pendidikan multikultural. Kegiatan belajar dan mengajar yang akan berkonsentrasi tidak hanya pada kompetensi kejuruan, kapasitas ekonomi dan keterampilan manajemen tetapi juga pada nilai-nilai manusiawi. Untuk itu semua sivitas di SMK perlu: 1) menghargai budaya manapun; 2) mengembangkan toleransi dan simpati untuk memiliki dan kemauan untuk bekerja dan hidup dengan orang-orang lain dari berbagai latar belakang, kepentingan dan gaya hidup; 3) mengembangkan rasa menghormati orang lain, mempertimbangkan kepentingan mereka dan peka dalam melakukan hubungan interpersonal, berkomunikasi dan menjada etika kesopanan; 4) mandiri dan rasional; 5) menerima pencarian makna yang ditawarkan oleh agama, budaya, adat-istiadat, humanisme, dan lainnya yang dihargai sebagai sikap hidup bersama.

\section{Praktik dan Problematik Pembelajaran Pendidikan Multikultural dan Upaya Sistematis Untuk Mengatasinya}

Dalam kerangka strategi pembelajaran, pembelajaran berbasis multikultural diharapkan dapat mendorong terjadinya proses imajinatif, metaforik, berpikir kreatif dan sadar budaya. Namun pada prakteknya, penggunaan budaya lokal (etnis) dalam pembelajaran berbasis multikultural tidak terlepas dari berbagai problematik yang terdapat dalam setiap komponen pembelajaran, sejak persiapan awal dan implementasinya. Beberapa permasalahan awal pembelajaran berbasis multikultural pada tahap persiapan awal, antara lain: 1) guru kurang mengenal budayanya sendiri, budaya lokal maupun budaya peserta didik; 2) guru kurang menguasai garis besar struktur dan budaya etnis peserta didiknya, terutama dalam konteks mata pelajaran yang akan diajarkannya; dan 3) rendahnya kemampuan guru dalam mempersiapkan peralatan yang dapat merangsang minat, ingatan, dan pengenalan kembali peserta didik terhadap khasanah budaya masing-masing dalam konteks budaya masing-masing dalam konteks pengalaman belajar yang diperoleh.

Untuk mengaktualisasikan pendidikan multikultural haruslah memperhatikan berbagai dimensi yang saling berelasi satu sama lain. Banks (2007, pp.83-85) memberikan panduan dimana ada lima dimensi pendidikan multikultur yang seharusnya secara simultan dilakukan, yaitu: integrasi materi (content integration), proses pembentukan pengetahuan (knowledge construction process), reduksi prasangka (prejudice reduction), pendidikan/ perlakuan pedagogi tanpa pandang bulu (equity pedagogy), dan pemberdayaan budaya sekolah dan struktur sosial (empowering school culture and social structure).

Integrasi konten adalah upaya guru memberikan atau menggunakan contoh dan materi dari berbagai budaya dan kelompok untuk mengajarkan konsep kunci, prinsip, generalisasi, teori dan lain-lain ketika mengajar satu topik atau mata pelajaran tertentu. Dimensi ini digunakan oleh guru untuk memberikan keterangan dengan 'poin kunci' pembelajaran dengan merefleksi materi yang berbeda-beda. Secara khusus, para guru menggabungkan kandungan materi pembelajaran ke dalam kurikulum dengan beberapa 
cara pandang yang beragam. Salah satu pendekatan umum adalah mengakui kontribusinya, yaitu guru-guru bekerja ke dalam kurikulum mereka dengan membatasi fakta tentang semangat kepahlawanan dari berbagai kelompok. Di samping itu, rancangan pembelajaran dan unit pembelajarannya tidak dirubah. Dengan beberapa pendekatan, guru menambah beberapa unit atau topik secara khusus yang berkaitan dengan materi multikultural. Sebagai contoh, ketika guru SMK mengajar topik menggambar motif batik, kemudian dikaitkan dengan berbagai macam motif batik di berbagai daerah penghasil batik di Indonesia. Artinya, yang dimaksud dengan integrasi konten adalah mengintegrasikan pendidikan multikultur ke dalam mata pelajaran/topik pelajaran. Dengan kata lain, sambil belajar biologi, terjadi penyadaran akan perbedaan budaya.

Akan tetapi dapat timbul problematik dalam "seleksi dan integrasi isi" (content selection and integration) mata pelajaran, yaitu: a) sejauh mana guru mampu memilih aspek dan unsur budaya yang relevan dengan isi dan topik mata pelajaran; dan b) sejauh mana guru dapat mengintegrasikan budaya lokal dalam mata pelajaran yang diajarkan, sehingga pembelajaran lebih bermakna bagi peserta didik. Sebagai upaya untuk mengatasi problematik tersebut, penulis menawarkan beberapa petunjuk untuk membantu guru dalam mengintegrasikan isi tentang kelompok etnis ke dalam pembelajaran dalam pendidikan multikultural, yaitu: 1) guru dituntut untuk mempunyai pengetahuan yang luas tentang beragam budaya; 2) sensitif dengan sikap dan perilaku rasial, gender, status sosial, dan lainnya; 3) membawa citra positif tentang berbagai kelompok etnis; 4) menggunakan buku, film, video, dan rekaman yang dijual di pasaran untuk pelengkap buku teks dari kelompok etnis dan menyajikan perspektif kelompok etnis pada siswa; 5) berbagi kisah etnis dan budaya dengan siswa; 6) sensitif dengan tahap perkembangan dari siswa; dan 7) gunakan teknik belajar yang kooperatif dan kerja kelompok untuk meningkatkan integrasi ras, etnis, dan status sosial di sekolah dan di kelas

Proses pembentukan pengetahuan adalah suatu dimensi dimana para guru membantu siswa untuk memahami beberapa perspektif dan merumuskan kesimpulan yang dipengaruhi oleh disiplin pengetahuan yang mereka miliki. Dimensi ini juga berhubungan dengan pemahaman para pelajar terhadap perubahan pengetahuan yang ada pada diri mereka sendiri. Dimensi ini berupaya membantu siswa untuk memahami, mencari tahu, dan menentukan bagaimana suatu pengetahuan atau teori pada dasarnya secara implisit tercipta karena adanya pengaruh budaya tertentu, kalangan tertentu, kelompok dengan status sosial tertentu yang terjadi pada saat itu. Sebagai contoh, ketika guru SMK membahas topik tentang Galileo yang menghasilkan teori heliosentris yang menumbangkan asumsi geosentris yang terjadi pada masa dimana pengaruh agama saat itu sangat dominan. Sehingga, Galileo harus dihukum mati karena teorinya, namun belakangan teori tersebut dipakai oleh masyarakat dunia. Di sini guru harus menjelaskan mengapa hal itu sampai terjadi dengan mengungkapkan pengaruh budaya masyarakat di sana pada waktu itu.

Problematik yang dapat timbul pada dimensi proses pembentukan pengetahuan adalah: a) kurangnya pengetahuan guru dalam memilih aspek budaya yang tepat sehingga dapat membantu peserta didik untuk memahami konsep kunci secara lebih tepat; dan b) kurangnya pengetahuan guru dalam menggunakan frame of reference dari budaya tertentu dan mengembangkannya dalam perspektif ilmiah. Yang dapat dilakukan guru untuk mengatasi masalah tersebut adalah: a) menambah wawasan dengan membaca buku, atau penelurusan internet, dan b) melatih pengembangan frame of reference dari budaya dalam perspektif ilmiah melaui diskusi dengan guru lain atau kelompok kerja guru.

Reduksi prejudice adalah upaya guru membantu siswa mengembangkan sikap positif terhadap perbedaan (baik dari sisi suku, budaya, ras, gender, status sosial, dll.) Sebagai contoh, adalah tidak benar kalau guru mendorong sikap atau prasangka yang menganggap bahwa orang Papua yang berkulit hitam adalah terbelakang, bodoh dan lain-lain. Prejudice yang tidak benar terhadap gender, ras, budaya dan lain-lain dalam proses interaksi di sekolah inilah yang harus dihindari.

Problematik yang dapat muncul dalam dimensi ini adalah kurangnya perhatian/ sensifitas guru dalam meluruskan prejudice negatif yang dapat terjadi di kalangan siswa. Upaya yang harus dilakukan guru untuk 
mengatasi problematik tersebut adalah guru berkewajiban meluruskan asumsi dan prejudice negatif seperti itu. Salah satu cara mengurangi prejudice ini adalah dengan melibatkan siswa melakukan aktifitas bersama dengan mereka yang terdiri dari berbagai status sosial, ras, gender dan lain-lain. Dalam dimensi ini guru dituntut untuk melakukan banyak usaha dalam membantu siswa mengembangkan perilaku positif tentang perbedaan kelompok. Sebagai contoh, ketika siswa SMK masuk sekolah dengan perilaku negatif dan memiliki kesalah-pahaman terhadap ras atau etnik yang berbeda dan kelompok etnik lainnya, pendidikan dapat membantu siswa mengembangkan perilaku intergroup yang lebih positif, penyediaan kondisi yang mapan dan pasti. Dua kondisi yang dimaksud adalah bahan pembelajaran yang memiliki citra yang positif tentang perbedaan kelompok dan menggunakan bahan pembelajaran tersebut secara konsisten dan terus-menerus. Penggunaan teksbook multikultural atau bahan pengajaran lain dan strategi pembelajaran yang kooperatif diharapkan dapat membantu para pelajar untuk mengembangkan perilaku dan persepsi terhadap ras yang lebih positif. Jenis strategi dan bahan dapat menghasilkan pilihan para pelajar untuk lebih bersahabat dengan ras luar, etnik dan kelompok budaya lain.

Perlakuan pedagodik tanpa pandang bulu (equity pedagogy) adalah upaya guru memperlakukan secara sama tanpa pandang bulu dalam proses pembelajaran di kelas. Dimensi ini memperhatikan cara-cara dalam mengubah fasilitas pembelajaran sehingga mempermudah pencapaian hasil belajar pada sejumlah siswa dari berbagai kelompok. Strategi dan aktivitas belajar di SMK diupayakan memperlakukan pendidikan secara adil, antara lain dengan bentuk kerjasama (cooperatve learning), dan bukan dengan cara-cara yang kompetitif (competition learning). Hal ini juga menyangkut pendidikan yang dirancang untuk membentuk lingkungan SMK, menjadi banyak jenis kelompok, termasuk kelompok etnik, wanita, dan para pelajar dengan kebutuhan khusus yang akan memberikan pengalaman pendidikan persamaan hak dan persamaan memperoleh kesempatan belajar. Hal ini akan terlihat dari metode yang digunakan, cara bertanya, penunjukkan siswa, pengelompokkan siswa, dan sebagainya.
Problematik yang dapat timbul dalam equity pedagogy ini adalah apabila guru terlalu banyak memakai budaya etnis atau kelompok tertentu dan (secara tidak sadar) menafikan budaya kelompok lain. Yang harus dilakukan guru dalam hal ini adalah guru harus berupaya untuk memiliki "khasanah budaya" mengenai berbagai unsur budaya dalam tema tertentu.

Pemberdayaan budaya sekolah dan struktur sosial adalah proses merestrukturisasi dan reorganisasi sekolah sehingga siswa dari beragam ras, suku, kelas sosial akan mengalami dan merasakan pemberdayaan dan persamaan budaya. Dimensi ini penting dalam memperdayakan budaya siswa yang dibawa ke sekolah yang berasal dari kelompok yang berbeda.

Dalam menyusun struktur sosial SMK memanfaatkan potensi budaya siswa yang beranekaragam sebagai karakteristik struktur SMK setempat, misalnya berkaitan dengan praktik kelompok, iklim sosial, latihanlatihan, partisipasi ekstra kurikuler dan penghargaan staff dalam merespon berbagai perbedaan yang ada di SMK. Dengan demikian, semangat multikulturalisme harus tercermin dalam segala aktifitas di SMK. Hal ini menuntut adanya perubahan baik dari sisi literasi multikultur pendidik dan tenaga kependidikan, kebijakan sekolah, struktur organisasi, iklim sekolah dan lain-lain.

Banks (2002, pp.30-32) mengemukakan empat pendekatan yang mengintegrasikan materi pendidikan multikultural ke dalam kurikulum ataupun pembelajaran di sekolah yang bila dicermati relevan untuk diimplementasikan di sekolah di SMK, yaitu: 1) pendekatan kontribusi (the contributions approach); 2) pendekatan Aditif (Aditive Approach); 3) pendekatan transformasi (the transformation approach); dan 4) pendekatan aksi sosial (the social action approach).

Pendekatan kontribusi (the contributions approach) paling sering dilakukan dan paling luas dipakai dalam fase pertama dari gerakan kebangkitan etnis. Substansi pendidikan multikultural pada tahap ini adalah menanamkan pada siswa bahwa manusia yang hidup di sekitarnya dan di tempat lain serta di dunia ini sangat beragam. Seperti berbagai jenis makanan, pakaian, dan lain-lain dari berbagai daerah. Dengan demikian siswa mengerti bahwa ada cara yang berbeda tetapi 
maksud dan nilainya sama. Sehingga mereka dapat belajar untuk menerima perbedaan dengan proses dan rasa yang menyenangkan. Akhirnya siswa merasa berbeda itu bukanlah masalah, tetapi anugerah.

Pada Pendekatan aditif (aditive approach) dilakukan penambahan materi, konsep, tema, dan perspektif terhadap kurikulum tanpa mengubah struktur, tujuan dan karakteristik dasarnya. Pendekatan aditif ini sering dilengkapi dengan penambahan buku (cerita rakyat dari berbagai daerah atau negara lain), media pembelajaran berbasis multikultural misalnya $\mathrm{CD}$ pembelajaran cerita berbagai daerah/negara, modul pendidikan multikultural, atau bidang bahasan terhadap kurikulum tanpa mengubahnya secara substansif. Hal ini dilakukan untuk menanamkan pengetahuan yang luas bagi siswa. Rasa ketertarikan akan keragaman yang diperoleh di dalam kelas akan memotivasi siswa untuk tahu lebih banyak dengan membaca, melihat di internet, berkunjung, bertanya pada yang lebih tahu dan sebagainya. Dengan wawasan yang lebih luas tentang keragaman budaya, kehidupan, persahabatan, pengetahuan, siswa akan tumbuh menjadi orang yang inklusif, mudah menerima yang berbeda, toleran dan menghargai orang lain. Selain itu akan mudah berinteraksi dengan lingkungan yang baru ataupun yang kompleks.

Pendekatan tranformasi (the transformation approach) berbeda secara mendasar dengan pendekatan kontribusi dan aditif. Pada pendekatan transformasi mengubah asumsi dasar kurikulum dan menumbuhkan kompetensi siswa dalam melihat konsep, isu, tema, dan problem dari beberapa perspektif dan sudut pandang etnis. Bank (1993) menyebut ini proses multiple acculturation sehingga rasa saling menghargai, kebersamaan dan cinta sesama dapat dirasakan melalui pengalaman belajar. Konsepsi akulturasi ganda (multiple acculturation conception) dari masyarakat dan budaya negara mengarah pada perspektif bahwa memandang peristiwa etnis, sastra, musik, seni dan pengetahuan lainnya sebagai bagian integral dari yang membentuk budaya secara umum. Budaya kelompok dominan hanya dipandang sebagai bagian dari keseluruhan budaya yang lebih besar.

Pendekatan aksi sosial (the social action approach) mencakup semua elemen dari pendekatan transformasi, namun menam- bah komponen yang mempersyaratkan siswa membuat aksi yang berkaitan dengan konsep, isu atau masalah yang dipelajari dalam unit. Tujuan utama dari pengajaran dalam pendekatan ini adalah mendidik siswa melakukan untuk kritik sosial dan mengajari mereka keterampilan pembuatan keputusan untuk memperkuat siswa dan membantu mereka memperoleh pendidikan politis, sekolah membantu mereka menjadi kritikus sosial yang reflektif dan partisipan yang terlatih dalam perubahan sosial. Siswa memperoleh pengetahuan, nilai, dan keterampilan yang mereka butuhkan untuk berpartisipasi dalam perubahan sosial sehingga kelompok - kelompok etnis, ras, dan golongan-golongan yang terabaikan dan menjadi korban dapat berpartisipasi penuh dalam masyarakat.

Dalam mengimplementasikan pendekatan-pendekatan pendidikan multikultural sebagaimana diuraikan di atas, banyak bergantung pada peran dan kemampuan guru dalam multikulturalisme. Karena itu peran guru di dalam pendidikan multikultural di sekolah sangatlah penting. Adapun peran guru yang relevan diterapkan di SMK adalah sebagai berikut.

\section{Membangun Paradigma Keberagamaan Inklusif di Lingkungan Sekolah}

Guru SMK sebagai orang dewasa dan kebijakan SMK harus menerima bahwa ada agama lain selain agama yang dianutnya. Ada pemeluk agama lain selain dirinya yang juga memeluk suatu agama. Dalam sekolah yang muridnya beragam agama, SMK harus melayani kegiatan rohani semua siswanya secara baik. Hilangkan kesan mayoritas minoritas siswa menurut agamanya. Setiap kegiatan keagamaan atau kegiatan apapun di SMK biasakan ada pembauran untuk bertoleransi dan membantu antar siswa yang beragama berbeda. Guru dan kebijakan di SMK tidak mengungkapkan secara eksplisit, radikal, dan provokatif dalam wujud apapun, karena di luar sekolah itu siswa akan bertemu, bergaul, dan bekerja sama dengan orang lain yang berbeda agama. Sebagai bahan renungan, seorang guru harus peka dan bijaksana menjelaskan sejarah Perang Salib, bom Bali, konflik antar pemeluk agama di Maluku, terorisme, dan sebagainya. Jangan sampai ada ketersinggungan sekecil apapun karena kecerobohan ungkapan guru. Sekecil apapun 
singgungan tentang agama akan membekas dalam benak siswa yang akan dibawanya sampai dewasa.

\section{Menghargai Keragaman Bahasa di Sekolah}

Dalam suatu sekolah bisa terdiri dari guru, tenaga kependidikan, dan siswa yang berasal dari berbagai wilayah dengan keragaman bahasa, dialek, dan logat bicara. Meski ada bahasa Indonesia sebagai bahasa pengantar formal di sekolah, namun logat atau gaya bicara selalu saja muncul dalam setiap ungkapan bahasa, baik lisan maupun tulisan. SMK perlu memiliki peraturan yang mengakomodasi penghargaan terhadap perbedaan bahasa. Guru serta warga SMK yang lain tidak boleh mengungkapkan rasa "geli" atau "aneh" ketika mendengarkan atau membaca ungkapan bahasa yang berbeda dari kebiasaannya. Semua warga SMK bersikap apresiatif dan akomodatif terhadap perbedaan-perbedaan itu. Perbedaan yang ada seharusnya menyadarkan kita bahwa kita sangat kaya budaya, mempunyai teman-teman yang unik dan menyenangkan, serta dapat bertukar pengetahuan berbahasa agar kita semakin kaya wawasan.

\section{Membangun Sikap Sensitif Gender di Sekolah}

"Dasar perempuan, cerewet dan bisanya menangis!". "Mentang-mentang cowok, jangan sok kuasa ngatur-ngatur di kelas ya!"." Syarat pengurus ekstrakurikuler adalah ketua harus cowok, sekretarisnya cewek, seksi perlengkapan cowok, seksi konsumsi cewek,....". Contoh ungkapan-ungkapan itu harus dihapus dari benak dan kebiasaan guru, siswa, dan warga sekolah yang lain. Pembagian tugas, penyebutan contoh-contoh nama tokoh, dan sebagainya harus proporsional antara laki-laki dan perempuan. Tak ada yang lebih dominan atau sebaliknya minoritas antara gender lakilaki dan perempuan. Dengan tetap mempertimbangkan nilai-nilai kodrati, penerapan gender dalam fungsi-fungsi pembelajaran di SMK harus proporsional karena setiap siswa laki-laki dan perempuan memiliki potensi masing-masing. Perempuan jadi pemimpin, laki-laki mengurusi konsumsi, atau yang lain saat ini bukan sesuatu yang tabu. Siswa berhak mengembangkan potensinya dengan baik tanpa bayang-bayang persaingan gender. Reward dapat diberikan pada pada siapapun dengan gender apapun yang mampu ber- prestasi, sebaliknya beri punishment yang tegas mendidik diberikan terhadap sikap, ucapan, dan perilaku yang menyinggung perbedaan gender.

\section{Membangun Pemahaman Kritis dan Empati terhadap Ketidakadilan serta Perbedaan Sosial}

Pelayanan pendidikan dan penegakan peraturan sekolah tidak boleh mempertimbangkan status sosial siswa. Siswa dibaurkan dari beragam status sosial dalam kelompok dan kelas untuk berinteraksi normal di sekolah. Meskipun begitu, guru dan siswa SMK harus tetap memahami perbedaan sosial yang ada di antara teman-temannya. Pemahaman ini bukan untuk menciptakan perbedaan, sikap lebih tinggi dari yang lain, atau sikap rendah diri bagi yang kurang, namun untuk menanamkan sikap syukur atas apapun yang dimiliki. Selanjutnya dikembangkan kepedulian untuk tidak saling merendahkan namun saling mendukung menurut kemampuan masing-masing. Sebaiknya sikap empati dan saling membantu tidak hanya ditanamkan di lingkungan sekolah saja. Suatu waktu siswa bisa diajak berkegiatan sosial di luar sekolah seperti di panti asuhan, panti jompo, dan sebagainya. Atau bila ada musibah di antara warga sekolah atau daerah lain siswa diajak berdoa dan memberikan sumbangan. Sekecil apapun doa, ucapan simpati, jabat tangan, pelukan, atau bantuan material akan sangat bermakna bagi pembentukan karakter siswa juga siapapun yang menjadi obyek empati.

\section{Membangun Sikap Anti Diskriminasi Etnis}

Sekolah bisa jadi menjadi Indonesia mini atau dunia mini, dimana berbagai etnis menuntut ilmu bersama di sekolah. Di sekolah bisa jadi suatu etnis mayoritas terhadap etnis lainnya. Tapi perlu dipahami, di sekolah lain etnis yang semula mayoritas bisa jadi menjadi minoritas. Hindari sikap negatif terhadap etnis yang berbeda. Sebagai misal ungkapan seperti ini, "Dasar Batak, ngeyel dan galak", "Heh si Aceh ya, slamat ya terhindar dari Tsunami", "Halo Papua Kritam (kriting dan hitam)", "Ssst, jangan dekat dengan orang Dayak, nanti dimakan lho". Di SMK perlu ditanamkan dan dibiasakan pergaulan yang positif, diberikan pemahaman bahwa inilah Indonesia yang hebat, warganya beraneka ragam 
suku atau etnis, bahasa, tradisi namun bisa bersatu karena sama-sama berbahasa Indonesia dan bangga menjadi bangsa Indonesia. Sebagai contoh bila bertemu saling bertegur sapa, "Halo Tigor, senang bertemu denganmu, kapan ya saya bisa berkunjung ke Danau Toba yang indah", "Wah, pemain bola dari Papua hebat-hebat ya, Emanuel Wanggai, Elly Eboy, dan lainnya. Suatu saat kamu bisa seperti mereka", dan sebaginya. Karena itu perlu membangun kultur dan kehidupan di SMK yang Bhinneka Tunggal Ika dengan interaksi dan komunikasi yang positif.

\section{Menghargai Perbedaan Kemampuan}

Tidak semua siswa berkemampuan sama atau standar. Dalam psikologi sosial dikenal istilah disability, artinya terdapat sebuah kondisi fisik dan mental yang membuat seseorang kesulitan mengerjakan sesuatu yang orang kebanyakan dapat mengerjakannya dengan mudah. Dalam orientasi awal masuk dan pengamatan proses guru dan siswa dapat saling memahami kelebihan dan kelemahan masing-masing. Karena siswa SMK yang sudah menjadi bagian warga sekolah, jangan sampai sikap, ucapan, dan perilaku yang meremehkan atau menter-tawakan kelemahan yang sudah dipahami. Hal itu sangat berdampak negatif, baik bagi siswa yang unggul maupun siswa yang lemah. Yang unggul akan merasa jumawa dengan keunggulannya sehingga bisa membuatnya lalai dan tidak berprestasi optimal. Bagi siswa yang lemah akan menjadi tidak termotivasi belajar dan merasa terkucilkan. Sebaiknya dibiasakan pembauran siswa unggul dan lemah dalam kelompok atau kelas agar terjadi pembimbingan sebaya, yang unggul semakin kuat pemahamannya tentang suatu materi dan merasa bermanfaat dengan ilmunya, serta yang kurang memperoleh guru sebaya yang lebih komunikatif dan merasa diterima oleh teman-temannya.

\section{Menghargai Perbedaan Umur}

Setiap individu siswa mengalami pertumbuhan fisik dan perkembangan kejiwaannya sesuai pertambahan umurnya. Guru SMK harus memahami ini, terutama tentang karakteristik psikologis dan tingkat kemampuan sesuai umurnya. Sebagai misal kemampuan menganalisis masalah dan berkarya siswa SMK kelas X akan berbeda dengan kelas XI, apalagi dibandingkan dengan siswa kelas XII, atau gurunya. Selain itu jangan sampai ada deskriminasi, sikap, ucapan, dan perilaku negatif diantara warga SMK dengan sebutan dominasi senior atas yunior, pelecehan berdasar perbedaan ukuran fisik, kata sebutan atau panggilan yang tidak disukai (misal "si Unyil" untuk siswa bertubuh kecil, "bayi ajaib" untuk siswa berusia lebih muda tapi pintar, "tuyul" untuk adik kelas yang berkepala gundul, dan sebagainya). Seharusnya yang lebih tua memberi teladan, memberi motivasi, memberi kepercayaan, demokratis, membimbing, mengasuh, dan melindungi yang lebih muda. Yang muda menghormati, sopan santun, menauladani kebaikan, dan membantu yang lebih tua.

\section{SIMPULAN}

Dari paparan tersebut, dapat ditarik beberapa kesimpulan sebgai berikut. Pertama, Pendidikan multikultural di Indonesia sangatlah penting, karena pendidikan multikultur ini berperan untuk menyatukan budaya bangsa, dalam arti tidak menjadikan budaya yang ada menjadi seragam, namun keberagaman yang dipandang sebagai kekayaan bangsa yang patut dijaga bersama. Jika peran dan tujuan tersebut tercapai secara maksimal, maka integrasi, persatuan dan kesatuan bangsa Indonesia akan tercapai.

Kedua, pendidikan multikultural adalah sebuah konsep yang dibuat dengan tujuan untuk menciptakan persamaan peluang pendidikan bagi semua siswa yang berbeda-beda ras, etnis, kelas sosial dan kelompok budaya. Tujuan penting lainnya dari konsep pendidikan multikultural adalah untuk membantu semua siswa agar memperoleh pengetahuan, sikap dan keterampilan yang diperlukan dalam menjalankan peran-peran seefektif mungkin pada masyarakat demokratik-pluralistik serta diperlukan untuk berinteraksi, negosiasi, dan komunikasi dengan warga dari kelompok be-ragam agar tercipta sebuah tatanan masyarakat bermoral yang berjalan untuk kebaikan bersama. Melalui pendidikan multikultural peserta didik diharapkan dapat dengan mudah mema-hami, menguasai, memiliki kompetensi yang baik, bersikap dan menerapkan nilainilai demokratis, humanisme dan pluralisme di sekolah dan di luar sekolah.

Ketiga, pentingnya pendidikan multikultural diberikan kepada siswa SMK dengan 
harapan agar mereka mampu memahami bahwa di dalam lingkungan mereka dan juga di lingkungan lain terdapat keragaman budaya. Keragaman budaya tersebut berpengaruh terhadap tingkah laku, sikap, pola pikir manusia sehingga manusia tersebut memiliki cara-cara (usage), kebiasaan (folk ways), aturan-aturan (mores) bahkan adat istiadat (customs) yang berbeda satu sama lain. Bila perbedaan itu tidak dapat dipahami dengan baik dan diterima dengan bijaksana, maka konflik (seperti perkelahian antar pelajar) akan mudah terjadi baik di lingkungan sekolah maupun di lingkungan masyarakat.

Keempat, diperlukan suatu upaya penerapan konsep yang sistematis dalam mengatasi praktik dan problematik pembelajaran pendidikan multikultural, yaitu: (a) untuk mengaktualisasikan pendidikan multikultural haruslah memperhatikan berbagai dimensi yang saling berelasi satu sama lain. Dengan menggunakan panduan lima dimensi pendidikan multikultur dari Banks, yaitu: integrasi materi (content integration), proses pembentukan pengetahuan (knowledge construction process), reduksi prasangka (prejudice reduction), pendidikan/perlakuan pedagogi tanpa pandang bulu (equity pedagogy), dan pemberdayaan budaya sekolah dan struktur sosial (empowering school culture and social structure), problematik yang timbul dapat diatasi dengan upaya meningkatkan peran seluruh warga sekolah, terutama guru; (b) dengan menggunakan empat pendekatan dari Banks yang mengintegrasikan materi pendidikan multikultural ke dalam kurikulum ataupun pembelajaran di sekolah yang bila dicermati relevan untuk diimplementasikan di SMK, yaitu: (1) pendekatan kontribusi (the contributions approach), (2) pendekatan aditif (Aditive Approach), (3) pendekatan transformasi (the transformation approach), dan (4) pendekatan aksi sosial (the social action approach); (c) meningkatkan peran guru di dalam pendidikan multikultural di SMK, di antaranya adalah sebagai berikut: (1) membangun paradigma keberagamaan inklusif di lingkungan sekolah, (2) menghargai keragaman bahasa di sekolah, (3) membangun sikap sensitif gender di sekolah, (4) membangun pemahaman kritis dan empati terhadap ketidakadilan serta perbedaan sosial, (5) membangun sikap anti diskriminasi etnis, (6) menghargai perbedaan kemampuan, dan (7) menghargai perbedaan umur.

\section{DAFTAR PUSTAKA}

Banks, James A. (1993). Teaching strategies for ethnic studies. Boston: Allyn and Bacon Inc.

Banks, James A. \& Cherry McGee Banks, (eds). (2001). Multicultural education issues and perspectives. New York: John Wiley and Sons.

Banks, James A. (2002). An introduction to multicultural education. Boston: Allyn \& Bacon.

Banks, James A. (2007). Educating citizens in a multicultural society. New York: Teacher College Press.

Billings, G.L. \& Gillborn, D. (2004). The routledge falmer reader in multicultural education. London \& New York: RoutledgeFalmer.

Gollnick, Donna M. (1983). Multicultural education in a pluralistik society. London: The CV Mosby Company.

Noel, Jana. (2000). Multicultural education. Connecticut: The McGraw-Hill Companies.

Zamroni. (2008). Multicultural education: philosophy, policy and practice vol.1. A reader. Yoyakarta: Graduate Program The State University of Yogyakarta.

Zamroni. (2010). The implementation of multicultural education. A reader. Yogyakarta: Graduate Program The State University of Yogyakarta.

Zamroni. (2011). Pendidikan demokrasi pada masyarakat multikultural. Yogyakarta: gavin Kalam Utama. 